University of Nebraska - Lincoln

DigitalCommons@University of Nebraska - Lincoln

June 2005

Revision of the southern South American endemic genus

Anomiopsoides Blackwelder, 1944 (Coleoptera: Scarabaeidae:

Scarabaeinae: Eucraniini) and description of its food relocation

behavior

Federico C. Ocampo

University of Nebraska - Lincoln, focampo2@unl.edu

Follow this and additional works at: https://digitalcommons.unl.edu/entomologypapers

Part of the Entomology Commons

Ocampo, Federico C., "Revision of the southern South American endemic genus Anomiopsoides Blackwelder, 1944 (Coleoptera: Scarabaeidae: Scarabaeinae: Eucraniini) and description of its food relocation behavior" (2005). Papers in Entomology. 127.

https://digitalcommons.unl.edu/entomologypapers/127

This Article is brought to you for free and open access by the Museum, University of Nebraska State at DigitalCommons@University of Nebraska - Lincoln. It has been accepted for inclusion in Papers in Entomology by an authorized administrator of DigitalCommons@University of Nebraska - Lincoln. 


\title{
Revision of the southern South American endemic genus Anomiopsoides Blackwelder, 1944 (Coleoptera: Scarabaeidae: Scarabaeinae: Eucraniini) and description of its food relocation behavior
}

\author{
Federico C. Ocampo \\ Systematics Research Collections, University of Nebraska State Museum, Lincoln, NE \\ Correspondence: W 436 Nebraska Hall, University of Nebraska State Museum, Lincoln, NE 68588-0541, USA; \\ email focampo@unlserve.unl.edu
}

\begin{abstract}
The South American genus Anomiopsoides Blackwelder is revised and now includes five species: A. aurita (Burmeister), A. biloba (Burmeister), A. catamarcae Martínez, A. cavifrons (Burmeister), and A. heteroclyta (Blanchard). The following species names are new synonyms of $A$. heteroclyta (Blanchard): A. aberrans Martínez, A. pereirai (Martínez), and A. xerophila Martínez. The following variety is a new synonym of A. biloba (Burmeister): A. biloba var. schaeferi (Martínez). Descriptions, diagnosis illustrations, and distribution maps are provided for all species. A key to species of the genus is provided. The biology and the food relocation behavior of Anomiopsoides species are described. A checklist of the tribe Eucraniini is presented.

\section{Resumen}

El género sudamericano Anomiopsoides Blackwelder es revisado y ahora contine cinco especies: A. aurita (Burmeister), A. biloba (Burmeister), A. catamarcae Martínez, A. cavifrons (Burmeister) y A. heteroclyta (Blanchard). Las siguentes especies son nuevos sinónimos de A. heteroclyta (Blanchard): A. aberrans Martínez, A. pereirai (Martínez) y A. xerophila Martínez. La siguiente variedad es un nuevo sinónimo de A. biloba (Burmeister): A. biloba var. schaeferi (Martínez). Se proveen descripciones, diagnosis y mapas de la distribución de cada especie. Se presenta una clave para las especies del género. El comportamineto de relocación del alimento de las especies de Anomiopsoides es descripto y su biología es discutida. Se presenta una lista taxonómica de la tribu Eucraniini.
\end{abstract}

Keywords: Behavior, dung beetles, taxonomy

\section{Introduction}

The genus Anomiopsoides Balckwelder is a relatively small dung beetle genus that belongs to the tribe Eucraniini (Coleoptera: Scarabaeidae: Scarabaeinae). Eucraniini is a unique tribe of dung beetles that is endemic to the Chaqueña and Monte biogeographic provinces in northwestern Argentina. Eucraniini consists of four genera: Anomiopsoides Blackwelder (five species), Ennearabdus 
van Lansberge (one species), Eucranium Brullé (seven species), and Glyphoderus Westwood (three species). The members of the tribe Eucraniini are unique in that they have very specialized ecological adaptations, exhibit unique behavior not seen in any other dung beetles, and occur only in specific desert-thorn habitats of Argentina. The taxonomic placement of the tribe has been enigmatic due to their unusual biology and appearance. It has been hypothesized that Eucraniini are the sister group to the Canthonini (Cambefort 1991), Phanaeini+Onitini (Zunino 1985; Zunino et al. 1989), and Scarabaeini (Mostert and Scholtz 1986). In more recent papers by me, it was determined that Eucraniini is a monophyletic group probably related to the Phanaeini (Phillips et al. 2002; F. C. Ocampo, in preparation); in these same papers, Anomiopsoides is placed as a sister group of the genus Glyphoderus Westwood. The species-level taxonomy has been enigmatic. Some species can be two times as large in one locality as in another or even in the same locality. The form of the head and pronotal armature can also vary greatly within a species. It is apparent that populations of Anomiopsoides species are genetically isolated due to their poor dispersal abilities (they are flightless), isolation of adequate habitat in mountain valleys, and human alteration and fragmentation of their preferred habitat (F. C. Ocampo, unpublished data).

Species of Anomiopsoides exhibit all the unusual traits typical of the tribe Eucraniini, including specialization for arid habitats, flightlessness, specialization on dry dung pellets, and the bizarre behavior of relocating food by grasping it with the forelegs and running forward with it (Zunino et al. 1989; Ocampo 2003, 2004).

This paper is a continuation of my work on the taxonomy and evolution of the food relocation behavior of the genera of Eucraniini. The aim of this paper is to provide a taxonomic revision of the genus Anomiopsoides. This includes new diagnoses and descriptions, a key to species, distributions, and description of their food relocation behavior.

\section{Taxonomic history}

Anomiopsoides heteroclyta (Blanchard), the first-described species in the genus, was originally placed in the genus Anomiopsis Westwood, 1837. Anomiopsis Westwood is a synonym of Eucranium Brullé, 1834. Burmeister (1861, p 62) proposed the name Anomiopsis as a "section” of Eucranium and created a homonym, even when in the same publication he considered the name Anomiopsis as a synonym of Eucranium. In the same publication, Burmeister (1861) described four species: A. aurita, A. biloba, A. cavifrons, and A. furcifera. Burmeister (1873) considered Anomiopsis as a subgenus of Eucranium. Gillet (1911) elevated Anomiopsis to the generic level. Martínez (1944) described one species, A. pereirai, and one variety, A. biloba var. schaeferi. Blackwelder (1944) advertised the mistake made by Burmeister (1861) and fixed it replacing the name Anomiopsis with Anomiopsoides. Martínez (1945a, 1945b) redescribed the genus Anomiopsoides, redescribed the known species, synonymized A. furcifera (Burmeister) with A. heteroclyta (Blanchard), and described three new species, A. aberrans, A. catamarcae, and A. xerophila. Zunino et al. (1989) reported their observation on the food relocation behavior of $A$. heteroclyta. Barbero and Palestrini (1993) described the larvae of A. cavifrons, the only known larva of the genus.

\section{Material and methods}

Observations on the biology and food relocation behavior of A. heteroclyta were carried out under natural conditions in Mendoza, La Rioja, and San Juan provinces, Argentina [Mendoza: Las Catitas; La Rioja: Aimogasta, Anillaco; San Juan: Encón (12 km E)], for a period of 15 days in January 
2002 and 3 days in January 2003. Observations on the biology and food relocation behavior of $A$. biloba were carried out under natural conditions in La Rioja province [Aimogasta (10 km E)] for a period of 5 days in January 2002. Observations on the biology and food relocation behavior of $A$. cavifrons were carried out under natural conditions in San Juan province [Encón (12 km E)] for 1 day in January 2003. Observations on the biology of A. aurita were carried out under natural conditions in La Rioja province [La Rioja (20 km N)] for 1 day in January 2002.

Body measurements, puncture density, puncture size, fovea density, fovea size, and density of setae are based on the following standards. Body length was measured from the apex of the pronotum (at the middle) to the apex of the elytra (head is excluded, the variable position of the head, and length of clypeal processes render it unpractical to include in the body length). Body width was measured across mid-pronotum. Puncture density was considered "dense" if punctures were nearly confluent to less than two puncture diameters apart, "moderately dense" if punctures were two to six diameters apart, and "sparse" if punctures were separated by more than six diameters apart. Puncture size was defined as "small" if punctures were $0.02 \mathrm{~mm}$ or smaller, "moderate" if $0.02-0.07 \mathrm{~mm}$, and "large" if $0.07 \mathrm{~mm}$ or larger. Surface was defined as "sparsely foveate" if there was (on average) a space of more than one diameter between foveae, "moderately dense" if there were $0.5-1$ diameters between foveae, and "densely foveate" if foveae were confluent or the space in between them is less than 0.5 diameters. Setae were defined as "sparse" if there were few setae, "moderately dense" if the surface was visible but with many setae, and "dense" if the surface was not visible through the setae. Elytral carinae were counted from the elytral suture. Specimen labels were copied literally using “/” between lines.

The Phylogenetic Species Concept (Wheeler and Platnik 2000) was used to diagnose species: "Species are the smallest aggregation of populations diagnosable by a unique combination of characters."

The results of this study were based on specimens from the following institutions, curators, and collections. The collections and their acronyms are as follows. ABTS, Andrew Smith Collection, Lincoln, NE; AMNH, American Museum of Natural History, New York, NY (L. Herman, Jr); BCRC, Brett C. Ratcliffe Collection, Lincoln, NE; CMNC, Canadian Museum of Nature, Ottawa, Canada (R. S. Anderson, F. Génier); CASC, California Academy of Sciences, San Francisco, CA (R. Brett); CNCI, Canadian National Collection of Insects, Ottawa, Canada (A. Davies); FCOC, Federico C. Ocampo Collection, Buenos Aires, Argentina; HAHC, Henry and Anne Howden Collection, Ottawa, Canada (H. Howden); IADIZA, Instituto Argentino de Investigaciones de Zonas Aridas (S. Roig-Juñent); LEMQ, Lyman Entomological Museum, McGill University, Ste. Anne de Bellevue, PQ, Canada (T. Wheeler, S. Boucher); MACN, Museo Argentino de Ciencias Naturales, Buenos Aires, Argentina (A. Bachmann); MLJC, Mary Liz Jameson Collection, Lincoln, NE; MLPA, Museo de La Plata, La Plata, Argentina (J. Schnack); MLUH, Martin-Luther-Universität, Zoologisches Institut, Halle, Germany (K. Schneider); MNHN, Muséum National d'Histoire Naturelle, Paris, France (J. Menier); UNSM, University of Nebraska State Museum, Lincoln, NE, USA (B. Ratcliffe, M. L. Jameson); USNM, United States National Museum, Washington, DC, USA (N. Adams).

\section{Anomiopsoides Blackwelder, 1944}

(Figures 1-6)

Anomiopsoides Blackwelder 1944, p 197.

Anomiopsis Burmeister 1861, p 62 (nec Westwood 1837). Synonym. 
Type species: Anomiopsis heteroclytus Blanchard, 1845, here designated.

\section{Description}

Form (Figure 1 ) Color black. Body globose, sides rounded. Length 9.5-23.0 mm, width 6.5-14.5 $\mathrm{mm}$.

Head (Figures 1 \& 2) Surface punctate to densely foveate; form rectangular, transverse. Frons flat or slightly depressed in middle; frontoclypeal suture present, complete, sinuous or curved. Clypeus well-developed. Clypeal surface obliquely angled downwards with respect to surface of frons or perpendicular in frontal view between clypeal medial processes. Clypeus with four anterior processes; medial processes large, parallel, convergent or divergent toward apex, with margins smooth; external process variable in shape, with internal margin smooth and external margin dentate or sinuous. Gena with external margin dentate or irregular. Eyes small, completely divided by gena, halves subequal in size. Antenna nine-segmented. Segment 1 as long as 2-6 combined. Antennal club three-segmented, elongated; first segment with a distinct glabrous area on external surface.

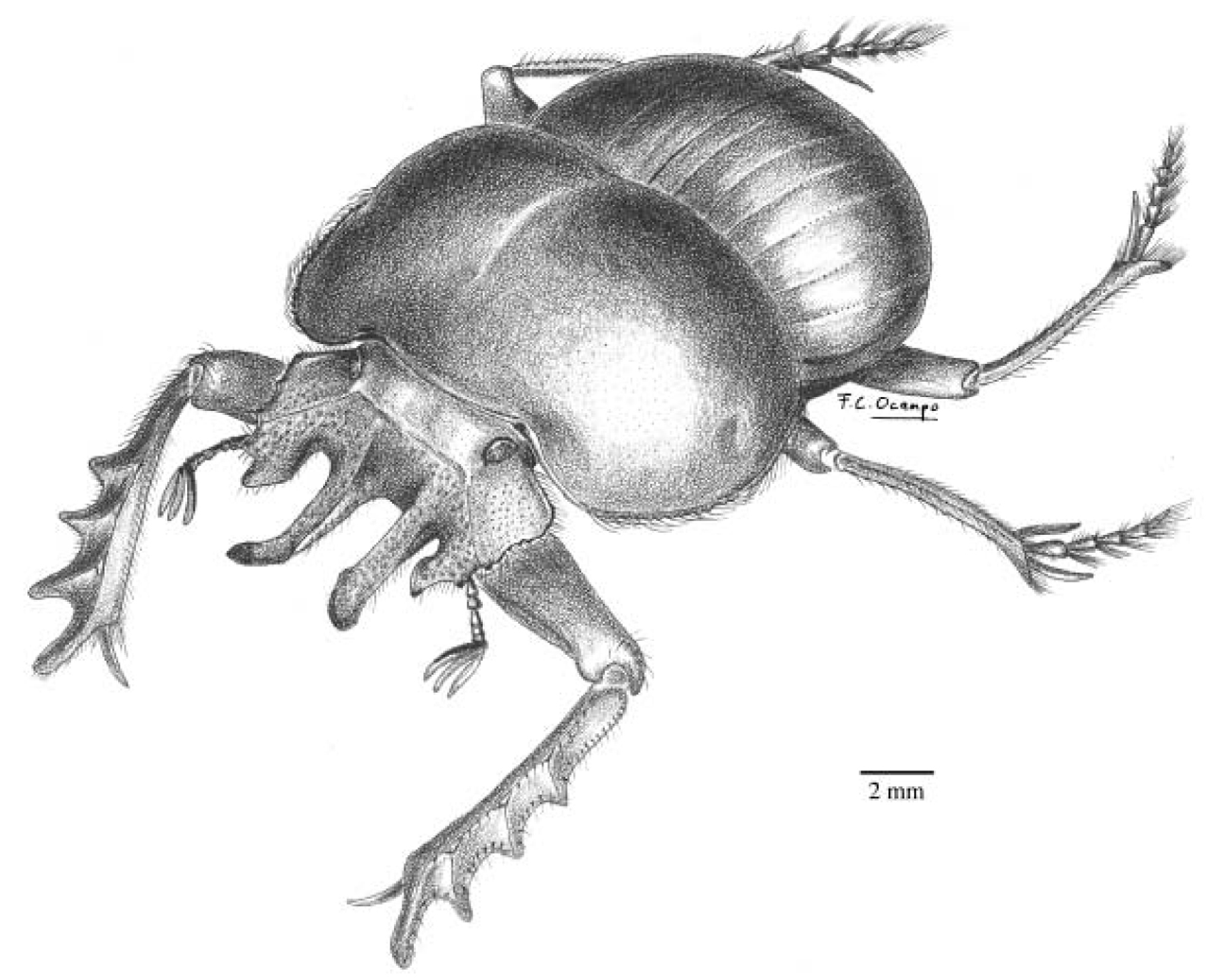

Figure 1. Habitus of Anomiopsoides heteroclyta (Blanchard). 
Pronotum Similar in both sexes, transverse, convex; with median longitudinal sulcus variably developed. Lateral portions with a single, irregular depression. All margins beaded; posterior margin slightly sinuous.

Elytron Globose, surface with eight striae; striae variably impressed. Pseudoepipleura present at level of 7 th elytral stria.

Hind wings Obsolete.

Venter Proepisternum convex, shiny, sparsely setose. Prosternum with posterior margin slightly pointed. Mesosternum transverse; mesometasternal suture broadly arcuate, concave in middle. Metasternum length 4.40-4.50 times width at middle. Abdominal sternites 2-6 with sutures distinct; sternite 5 narrower in males than in females; sternite 6 strongly narrowed at middle (males and females).

Legs ( Figure 1) Mesocoxae subparallel, slightly convergent posteriorly, separated at base. Protibia with surface punctate to foveate, with dorsomedial fringe of setae; apical margin oblique, truncate; external margin with four teeth; teeth with acute or rounded apex; protibial spur straight or curved on apex. Protarsi absent. Meso- and metatibae slender, with two dorsal and one ventral fringe of setae, setae arising from base of small denticles; apex expanded, with fringe of setae on margin. Mesotibia with two spurs, medial spur longer than external. Metatibia with one spur. Mesotarsus longer than metatarsus. Meso- and metatarsi unequal in size, becoming gracile toward apex, apex setose. Tarsal claws absent.

Male genitalia Symmetrical, variably sclerotized.

\section{Diagnosis}

The combination of the following characters will separate Anomiopsoides from all other Scarabaeinae in the New World: clypeus with four anterior processes well-developed (Figures 1, 2a-g); pronotum without horns or tubercles; mesocoxae not contiguous at the base; protarsi absent; mesotarsus longer than metatarsus; and hind wings obsolete.

\section{Natural history and food relocation behavior}

The genus Anomiopsoides is restricted to the Monte biogeographic province in northeastern Argentina from $26^{\circ}$ to $34^{\circ} \mathrm{S}$ latitude and between 200 and $1650 \mathrm{~m}$ elevation. The climate in this area is temperate-arid with very little rainfall (between 80 and $250 \mathrm{~mm}$ per year) (Roig-Juñent et al. 2001). The northern and central regions of the Monte province receive rains in the summer, but in the south it is colder and rainfall is distributed throughout the year (Morello 1958; Cabrera 1976). The dominant vegetation of this region is scrublands that, at times, can be very open. The landscape consists of sandy plains and plateaus and is characterized by the presence of mountain chains that define several longitudinal valleys.

Images and videos on the food relocation behavior and natural history of the tribe Eucraniini are available (see Ocampo 2003).

The behavior and biology of Anomiopsoides species are similar to those of the species of the genus Glyphoderus (Ocampo 2004). 
Under natural conditions, the period of surface activity of A. aurita, A. biloba, A. cavifrons, and A. heteroclyta is from 9:30 to 13:00 h, and from 17:00 to 19:00 h, depending on the atmospheric and soil temperature. No nocturnal surface activity was recorded for any species of Anomiopsoides. During the observations atmospheric temperature varied between 20 and $38^{\circ} \mathrm{C}$ in the shade. All species studied prefer open, sandy or clay soils with a $20-60 \%$ vegetation cover. Anomiopsoides species, as most of the Eucraniini, have a specialization for dehydrated dung pellets. Specimens were observed carrying pellets of "cuis chico" (Microcavia australis (Geoffroy Saint-Hilaire and D’Orbigny)), “cuis” (Galea musteloides Meyen), and goat. The use of dung pellets of "vizcacha” (Lagostomus maximus (Desmarest)) by A. heteroclyta was reported by Zunino et al. (1989). Specimens of A. biloba and A. heteroclyta did not take dry horse or cow dung even when it was offered, and they were not attracted to dung traps baited with fresh human or cow dung. Two species, $A$. biloba and $A$. cavifrons, use plant material as food source. Specimens of $A$. biloba were observed carrying small pieces of dry leaves and seeds (unidentified plant). Two specimens of $A$. biloba were observed "cutting" small leaves and seeds (that grow at ground level) using their clypeal processes. For that purpose, the beetles placed the leaf or seed in between the medial clypeal processes and pulled out with their head and pronotum. The use of plant material, including seeds, as a food source was also reported for the Australian genus Cephalodesmius Westwood (Monteith and Storey 1981; Halffter and Edmonds 1982). These authors agreed that the use of plant material by Cephalodesmius is in response to a particular set of ecological factors, and species of this genus use leaf litter as an alternative to dung as a food source. The use of plant material as food source by $\mathrm{A}$. biloba and A. cavifrons was observed occasionally, but plant material does not constitute the main food source of these species. Populations of Anomiopsoides species occur in isolated areas (usually not larger than $500 \mathrm{~m}^{2}$ ). Generally, large numbers of individuals of one or two species live in the same area and are commonly associated with rodent nests or goats. The occasional use of plant material by A. biloba and A. cavifrons could be a response to the intra- and interspecific competition observed in the relatively small area of foraging. When foraging, they run on four legs, keeping their forelegs motionless and in a horizontal position with respect to the surface. Adults run in zig-zags or randomly from their burrow (apparently searching for food). To carry the food, the beetles grasp it with the foretibiae and run forward using only their middle and hind legs. This behavior is known only for members of the tribe Eucraniini. Three other methods of overland transportation (without forming a food ball) are known among dung beetles (Halffter and Matthews 1966). In the first method, the beetles grasp the food with the forelegs and with the remaining legs walk backwards toward the burrow, carrying or dragging the food. This method was observed in Onthophagus Latreille, Copris Müller, Dichotomius Hope, Phanaeus MacLeay, and Phalops Erichson (Halffter and Matthews 1966). In the second method, called "butting," pieces of dung are rolled (not formed into a ball) by the beetles walking forward and pushing it with their head and forelegs. This method was observed in various species of Phanaeus (Halffter and Matthews 1966) and in Eucranium arachnoides Brullé (F. C. Ocampo, in preparation). The third method is found in the South African subgenus Scarabaeus (Pachysoma) MacLeay. Species of Pachysoma use their hind legs to grasp either dung or detritus, depending upon the species, in a pincher-like manner. Then an individual walks forwards dragging the food to its burrow. It is not clear how the beetles find their way back to the burrow (along with the shortest possible route). As described by Dacke and Warrant (2002), and Byrne et al. (2003), for the South African flightless dung beetles Scarabaeus rugosus (Hausman), S. rusticus (Boheman), Kheper nigroaeneus (Boheman), and Pachylomerus femoralis (Kirby) (Scarabaeinae: Scarabaeini) the beetles must rely on cues such as the pattern of 
polarized light. Beetles may use polarized light as a compass bearing that can be used to "calculate" the direction to the burrow. When the entrance of the burrow is reached, the beetles enter by walking forward rather than backward. Observations published by Zunino et al. (1989) regarding the above behavioral character suggested that the beetles drop the dung pellet and turn back and enter the nest walking backward while dragging the pellet. I have never observed this for any Eucraniini species (see Ocampo 2003). The burrow of Anomiopsoides is always previously dug. It is variable in depth (usually between 0.20 and $0.80 \mathrm{~m}$ long) and variable in slope (between 35 and $60^{\circ}$ with respect to ground surface). The tunnel may be straight or curved. The depth of the burrow is apparently associated with the depth where the beetle finds a certain level of soil moisture. Burrows are sometimes bifurcated near the end. The beetles store the food at the end of the burrow, and no special chamber is prepared for it. Between three and eight dung pellets are usually stored, and each pellet is carried independently. Sexual cooperation has been observed, and it follows the same behavior as that observed for individuals. No special brood chambers were observed in burrows constructed by pairs. During the hours where there is no surface activity, it is common to observe the entrance of the burrow obscured with sand or other substrate.

\section{Key to the species of Anomiopsoides}

Anomiopsoides species show considerable intraspecific variation due to particular conditions during an individual's development, environmental conditions of the area in which the specimen lived, and/or age of the specimen at the time it was collected. The above factors make identifications difficult for some Anomiopsoides specimens, particularly females.

1. Medial processes of clypeus with external margin broadly rounded or lobed and medial margin concave or straight (Figure 2b, e).

Medial processes of clypeus with external margin straight, slightly rounded or sinuous and medial margin straight or rounded (Figure 2a, c, d, f, g)

2. Medial processes of clypeus with external margin lobed (Figure 2e). Mesotibial external spur wider on apical third (Figure 3a)

. A. biloba (Burmeister) (male and female)

Clypeus with medial processes with medial margin broadly rounded (but not lobed) (Figure 2c). Mesotibial external spur simple, not or slightly wider on apical third (Figure 3b)................... catamarcae Martínez (male, female unknown)

3. Clypeal disc with large, deep fovea before and between medial processes ..........4

Clypeal disc without foveae before medial processes ..........................................5

4. Clypeus with medial processes long (longer than rest of head), with apex divergent (Figure 2c) A. cavifrons (Burmeister) (male) Clypeus with medial processes short (shorter or as long as rest of head), with apex pointed (Figure 2d) .............................. A. cavifrons (Burmeister) (female)

5. Clypeus with medial processes long (longer than rest of head), with apex divergent (Figure 2f) A. heteroclyta (Blanchard) (male) Clypeus with medial processes short (shorter or as long as the length of frons plus length of clypeal disc), with apex pointed (Figure 2a, g) 
6. Clypeal surface not perpendicular in frontal view between clypeal medial processes (Figure 2g)

A. heteroclyta (Blanchard) (female)

Clypeal surface perpendicular in frontal view between clypeal medial processes

(Figure 2a)

A. aurita (Burmeister) (male and female)
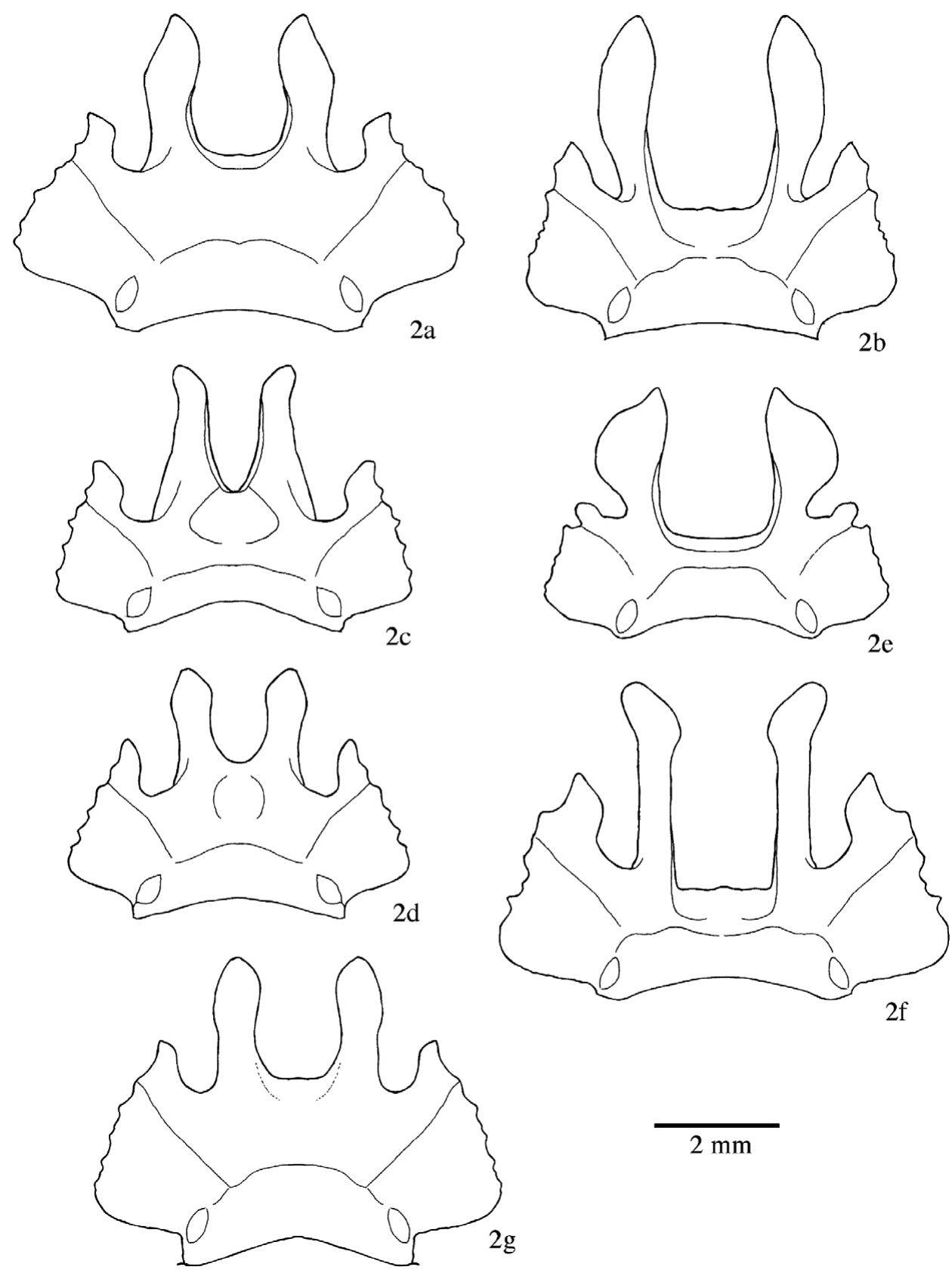

$2 \mathrm{~mm}$

Figure 2. Dorsal view of the head of: (a) Anomiopsoides aurita (Burmeister); (b) A. catamarcae Martínez; (c, d) A. cavifrons (Burmeister), male and female, respectively; (e) A. biloba (Burmeister); (f, g) A. heteroclyta (Bermeister), male and female, respectively. 


\section{Anomiopsoides aurita (Burmeister, 1861)}

(Figures 2a, 4)

Anomiopsoides aurita (Burmeister 1861, p 63).

Anomiopsis auritum Burmeister 1861, p 63.

Type material

Holotype female at MLUH labeled: “auritum/Nov./Argent. Br.” (handwritten); “Anomiopsoides aurita (Burm)/HOLOTYPE” (red holotype label).

Other material studied

Three females (FCOC, MLPA).

\section{Description}

Female Length 20.0-21.1 mm, width 12.2-14.6 mm. Color black, surface shiny to matte.

Head (Figure 2a) Shape subrectangular, transverse. Frons slightly foveate in apical half, punctate at base. Frontoclypeal and clypeogenal suture evident. Frontoclypeal suture elevated, sinuate. Clypeogenal surface strongly foveate. Genal posterior angle rounded; lateral margin irregular, setose. Clypeal surface obliquely angled downwards with respect to surface of frons, perpendicular in frontal view between clypeal medial processes; ventral surface short; ventral process developed, acute. Clypeal medial process developed, dorsal surface densely foveate, apex smooth, inner surface strongly to moderately foveate, sparsely setose; with medial margin convex and external margin sinuous; apex acute, reflexed. Clypeal lateral process developed, apex divergently pointed, with one external tooth.
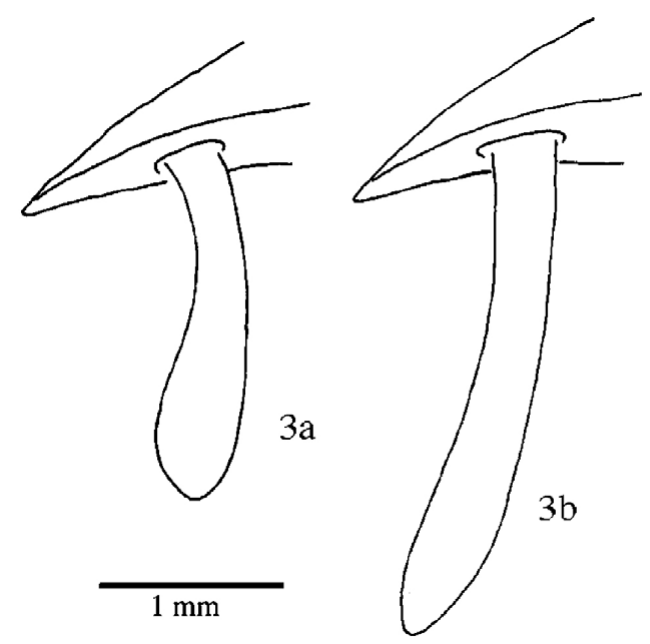

Figure 3. Mesotibial apex and external tibial spur of: (a) Anomiopsoides biloba (Burmeister); (b) A. catamarcae Martínez. 
Pronotum Surface punctate, punctures moderately dense, small to moderate in size. Lateral margin with long, dense setae on basal half, and with moderately dense, short setae on apical half; bead denticulate on apical half.

Elytron Striae variably impressed; punctate, punctures variably impressed, small. Intervals with minute tubercles.

Venter Metasternum with small, apical and posterior, longitudinal depressions.

Legs Protibial teeth with pointed or rounded apex. Protibial spur curved at apex. External mesotibial spur slightly curved at basal third, apex pointed.

\section{Diagnosis}

This species is recognized by the clypeal surface obliquely angled downwards with respect to the surface of the frons, perpendicular in frontal view and between clypeal medial processes (Figure 2a); the clypeal medial process developed, with the medial margin rounded, the external margin sinuous, and the apex acute and reflexed; and the clypeal lateral process developed, with the apex laterally pointed, and with one lateral tooth (Figure 2a).

\section{Remarks}

According to the original description (Burmeister 1861) and to Martínez (1945a, 1945b) males and females of $A$. aurita are similar, and the species does not exhibit sexual dimorphism.

\section{Distribution (Figure 4)}

Argentina: Catamarca: no data (1). La Rioja: La Rioja (20 km N) (2). Salta: Cafayate (Martínez 1945a). San Juan: no data (Martínez 1945a). Tucumán: no data (1).

Temporal data January (2).

\section{Anomiopsoides biloba (Burmeister, 1861)}

(Figures 2e, 3a, 4)

Anomiopsoides biloba (Burmeister 1861, p 63).

Anomiopsis bilobum Burmeister 1861, p 63.

Anomiopsis biloba var. schaeferi (Martínez 1944, p 40), new synonym.

\section{Type material}

Holotype female at MLUH labeled: “Catamarca”; “biloba/Burm/Argent.”; my red holotype label: “Anomiopsoides biloba (Burm)/HOLOTYPE.” Holotype Anomiopsoides bilobum var. schaeferi at MACN labeled: “Anomiopsoides bilobum var. schaeferi/Martínez det. 1944”; “Argentina/Catamarca/Tinogasta/Santa Rosa/Schaefer-leg/Feb 945”; "HOLOTYPE.”

New synonymy. There are no character-based differences between A. biloba (Burmeister) and A. biloba var. schaeferi (Martínez) and so I place this variety in synonymy. 


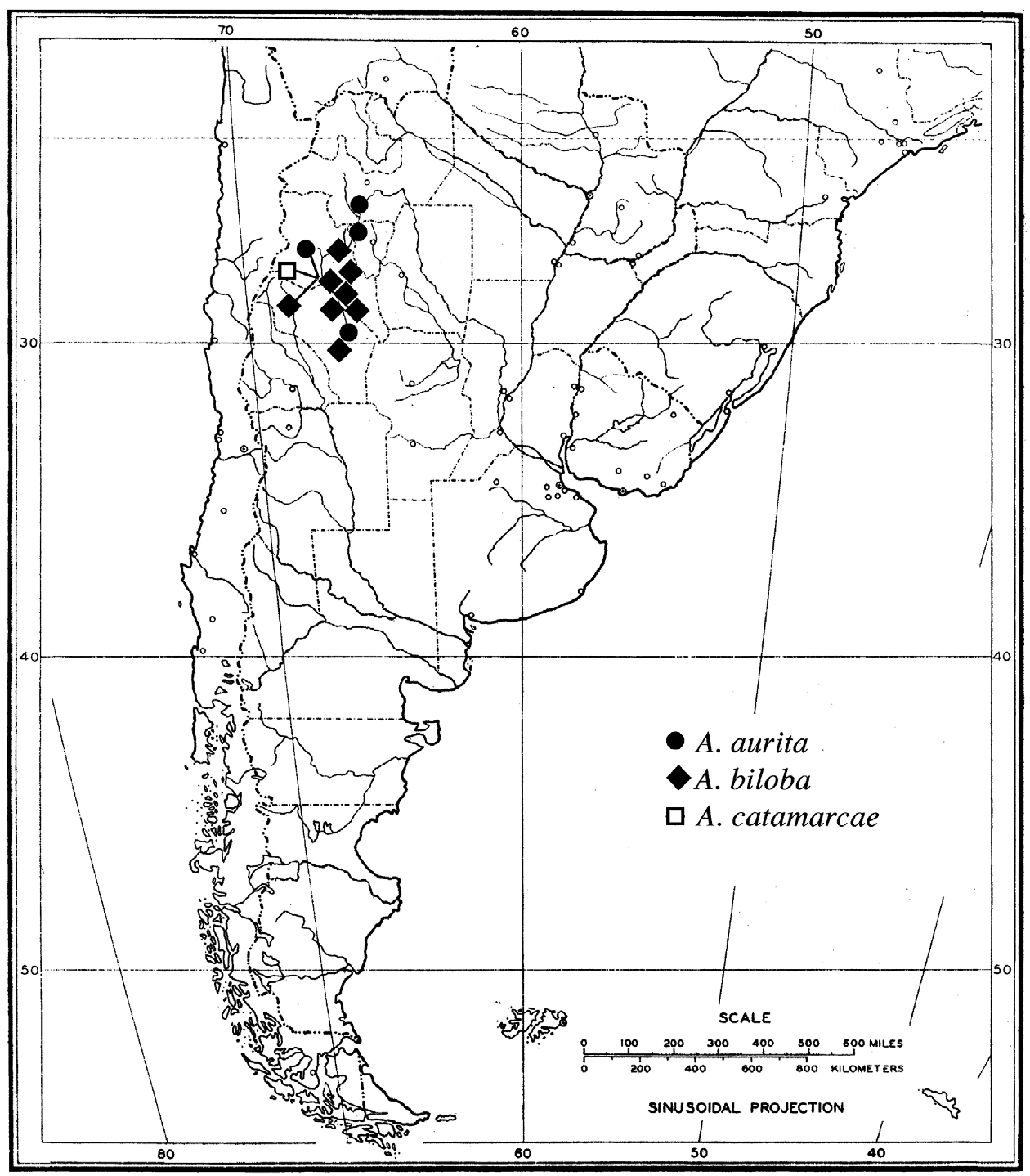

Figure 4. Distributional map of Anomiopsoides aurita (Burmeister), A. biloba (Burmeister), and A. catamarcae Martínez.

\section{Other material studied}

One hundred and twenty-five specimens (CMNC, FCOC, IADIZA, MLJC, MLPA, UNSM, USNM).

\section{Description}

Male and female Length 10.0-19.8 mm, width 5.7-12.5 mm. Color black, surface shiny to matte. 
Head (Figure 2e) Shape subrectangular, transverse. Frons sparsely foveate to punctate. Frontoclypeal and clypeogenal suture evident. Frontoclypeal suture elevated entirely or only on sides, sinuate. Clypeogenal surface strongly foveate. Genal posterior angle rounded; lateral margin irregular, setose. Clypeal surface strongly, obliquely angled downwards with respect to surface of frons, perpendicular in frontal view between clypeal medial processes; ventral surface short; ventral process developed, acute. Clypeal medial process developed, reflexed; dorsal surface strongly foveate, apex smooth; internal surface smooth to slightly foveate, with longitudinal carinae, ventral half with fringe of setae; inner margin slightly concave to concave, with dorsal lobe on middle; external margin broadly rounded (lobed); apex acute, reflexed or not. Clypeal lateral process poorly developed; with apex rounded or pointed, without lateral tooth.

Pronotum Surface punctate, punctures moderately dense to sparse, small to moderate in size. Lateral margin with long, dense setae on basal half, and moderately dense, short setae on apical half; bead denticulate on apical half.

Elytron Striae variably impressed, punctate; punctures variably impressed, small. Intervals without (rarely with) minute tubercles.

Venter Metasternum with small, apical and posterior, longitudinal depressions.

Legs Protibial teeth with pointed or rounded apex. Protibial spur curved on apex. External mesotibial spur slightly curved at basal third, wider on apical third, apex pointed or rounded (Figure 3a).

\section{Diagnosis}

This species is recognized by the clypeal surface strongly, obliquely angled downwards with respect to the surface of the frons, perpendicular in frontal view between clypeal medial processes (Figure 2e); the clypeal medial process developed, with the inner margin concave, with a dorsal lobe in middle, and the external margin broadly curved (lobed); and the clypeal lateral process poorly developed with the apex rounded or pointed, without a lateral tooth (Figure 2e).

\section{Distribution (Figure 4)}

Argentina: Catamarca: Andalgalá (27); Capayán-Chumbicha, Ruta Nacional 38 (2); Cerro Negro (1); Los Angeles (4); Tinogasta (6); Andalgalá (8 km E) (20). La Rioja: Aimogasta (13); Aimogasta (10 km E) (47); Patquía (1). Salta: no data (Martínez 1959). San Juan: no data (Martínez 1945a).

Temporal distribution January (55), February (22), March (3), December (36).

\section{Anomiopsoides catamarcae Martínez, 1945}

(Figures 2b, 3b, 4)

Anomiopsoides catamarcae Martínez 1945b, p 400.

\section{Type material}

Paratype male at CMNC labeled: “ARGENTINA/CATAMARCA/TINOGASTA/Coll. Marínez/ Feb 945” (handwritten); “H \& A COLLECTION/ex. A. Martínez coll.”; "PARATIPO”; 
“Anomiopsoides/catamarcae/sp. n. (handwritten)/A. Martínez Det. 1945.” Holotype at MACN (not studied).

Description

Male Length $21.8 \mathrm{~mm}$, width $12.9 \mathrm{~mm}$. Color black, surface shiny to matte.

Head (Figure 2b) Shape subrectangular, transverse. Frons slightly foveate. Frontoclypeal and clypeogenal suture evident. Frontoclypeal suture elevated entirely or only on sides, sinuate. Clypeogenal surface strongly foveate. Genal posterior angle rounded; lateral margin irregular, setose. Clypeal surface strongly, obliquely angled downwards with respect to surface of frons, perpendicular in frontal view between clypeal medial processes; ventral surface absent; ventral process developed, acute. Clypeal medial process developed, reflexed; dorsal surface strongly foveate, apex smooth; inner surface slightly foveate, with longitudinal carinae, ventral half with fringe of setae; inner margin slightly concave, with a dorsal lobe on apical third; external margin convex; apex acute, reflexed. Clypeal lateral process developed apex pointed, with one lateral tooth.

Pronotum Surface punctate, punctures moderately dense, small to moderate in size. Lateral margin with long, dense setae on basal half, and moderately dense, short setae on apical half; bead denticulate on apical half.

Elytron Striae variably impressed, punctate; punctures small. Intervals without minute tubercles.

Venter Metasternum with small, apical and posterior, longitudinal depressions.

Legs Protibial teeth with pointed apex. Protibial spur curved on apex. External mesotibial spur slightly curved at basal third, slightly wider on apical third, apex pointed (Figure 3b).

\section{Diagnosis}

This species is recognized by the clypeal surface strongly, obliquely angled downwards with respect to the surface of the frons, perpendicular in frontal view between clypeal medial processes (Figure 2b); the clypeal medial process developed, with the inner margin slightly concave, with a dorsal lobe on apical third, and the external margin convex; and the clypeal lateral process developed with the apex pointed, with one lateral tooth (Figure 2b). Females are unknown.

Distribution (Figure 4)

Argentina: Catamarca: Tinogasta (1).

Temporal distribution February (1).

\section{Anomiopsoides cavifrons (Burmeister, 1861)}

(Figures 2c, d, 5)

Anomiopsis cavifrons Burmeister 1861, p 63. 


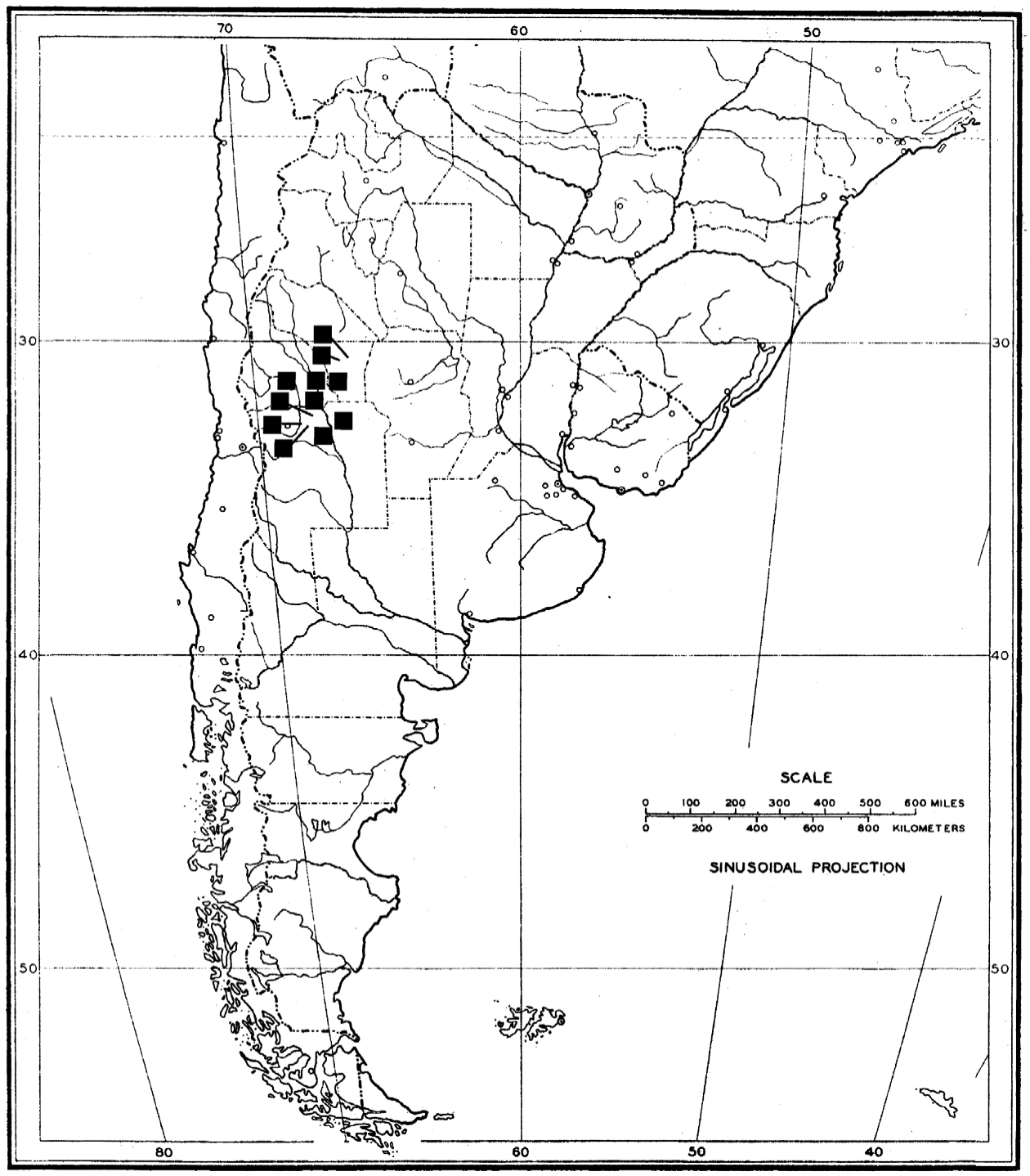

Figure 5. Distributional map of Anomiopsoides cavifrons (Burmeister).

\section{Type material}

Holotype male at MLUH labeled: "Pampa/occid.”; “cavifrons/Nov./Mend. Br.”

\section{Other material studied}

Thirty-six males and 44 females (ABTS, BCRC, CMNC, CNCI, FCOC, IADIZA, MLPA, UNSM).

\section{Description}

Male Length 9.9-14.5 mm, width 6.6-8.8 mm. Color black, surface shiny to matte. 
Head (Figure 2c) Shape subrectangular, transverse. Frons slightly foveate to punctate. Frontoclypeal and clypeogenal suture evident. Frontoclypeal suture elevated entirely or only on sides, sinuate. Clypeogenal surface strongly foveate. Genal posterior angle rounded; lateral margin irregular, setose. Clypeal surface obliquely angled downwards with respect to surface of frons, perpendicular in frontal view between clypeal medial processes; clypeal disc with a large, deep fovea before medial clypeal processes; ventral surface absent; ventral process developed, acute. Clypeal medial process developed, reflexed; dorsal and external surface strongly foveate, apex smooth; internal surface smooth to slightly foveate, with longitudinal carinae, ventral half with fringe of setae; inner margin sinuous, with a dorsal lobe at base; external margin straight; apex rounded or acute, divergent, reflexed. Clypeal lateral process developed, apex rounded or pointed, without or with one poorly developed lateral tooth.

Pronotum Surface punctate, punctures moderately dense to sparse, small to moderate in size. Lateral margin with long, dense setae on basal half, and moderately dense, short setae on apical half; bead denticulate on apical half.

Elytron Striae variably impressed, punctate; puntures variable impressed, small. Intervals with, rarely without, minute tubercles.

Venter Metasternum with small, apical and posterior, longitudinal depressions.

Legs Protibial teeth with pointed or rounded apex. Protibial spur curved on apex or not. External mesotibial spur slightly curved, apex pointed.

Female Length 8.6-12.9 mm, width 5.2-8.2. As male except in the following respects: clypeal surface obliquely angled downwards with respect to surface of frons, with a large, shallow fovea before medial clypeal processes; ventral surface developed; ventral process developed, acute (Figure 2d). Clypeal medial process developed, reflexed; dorsal and external surface strongly foveate, apex smooth; internal surface slightly foveate; inner and external margins slightly convex; apex rounded or acute, reflexed or not (Figure $2 \mathrm{~d}$ ).

\section{Diagnosis}

Males of this species are recognized by the clypeal disc with a large, deep fovea before the medial clypeal processes; the clypeal surface obliquely angled downwards with respect to the surface of the frons, and perpendicular in frontal view between the clypeal medial processes; the clypeal ventral surface absent; the clypeal medial process developed and reflexed, with the inner margin sinuous, and with a dorsal lobe at base, and the external margin straight, the apex divergent, reflexed; and the clypeal lateral process developed, with or without one poorly developed lateral tooth (Figure 2c). Females of this species are recognized by the clypeal disc with a large fovea before the medial clypeal processes (Figure 2d).

\section{Distribution (Figure 5)}

Argentina: Catamarca: no data (2). Mendoza: Desaguadero (2); Lavalle Ruta 142 km 45 (1); San Jurjo (2); Telteca (2); El Quince (5 km N) (1). La Rioja: Mascasin (18); Patquía (1); Punta de los 
Llanos (3); no data (1). San Juan: Bermejo (2); Caucete (1); Encón (12 km E) (55); Sierra Pie de Palo (3). San Luis: San Jerónimo (1).

Temporal distribution January (62), February (8), March (5), November (1), December (2).

Larva A description of the larvae of A. cavifrons was provided by Barbero and Palestrini (1993). The larva of this species is the only one known in the tribe Eucraniini.

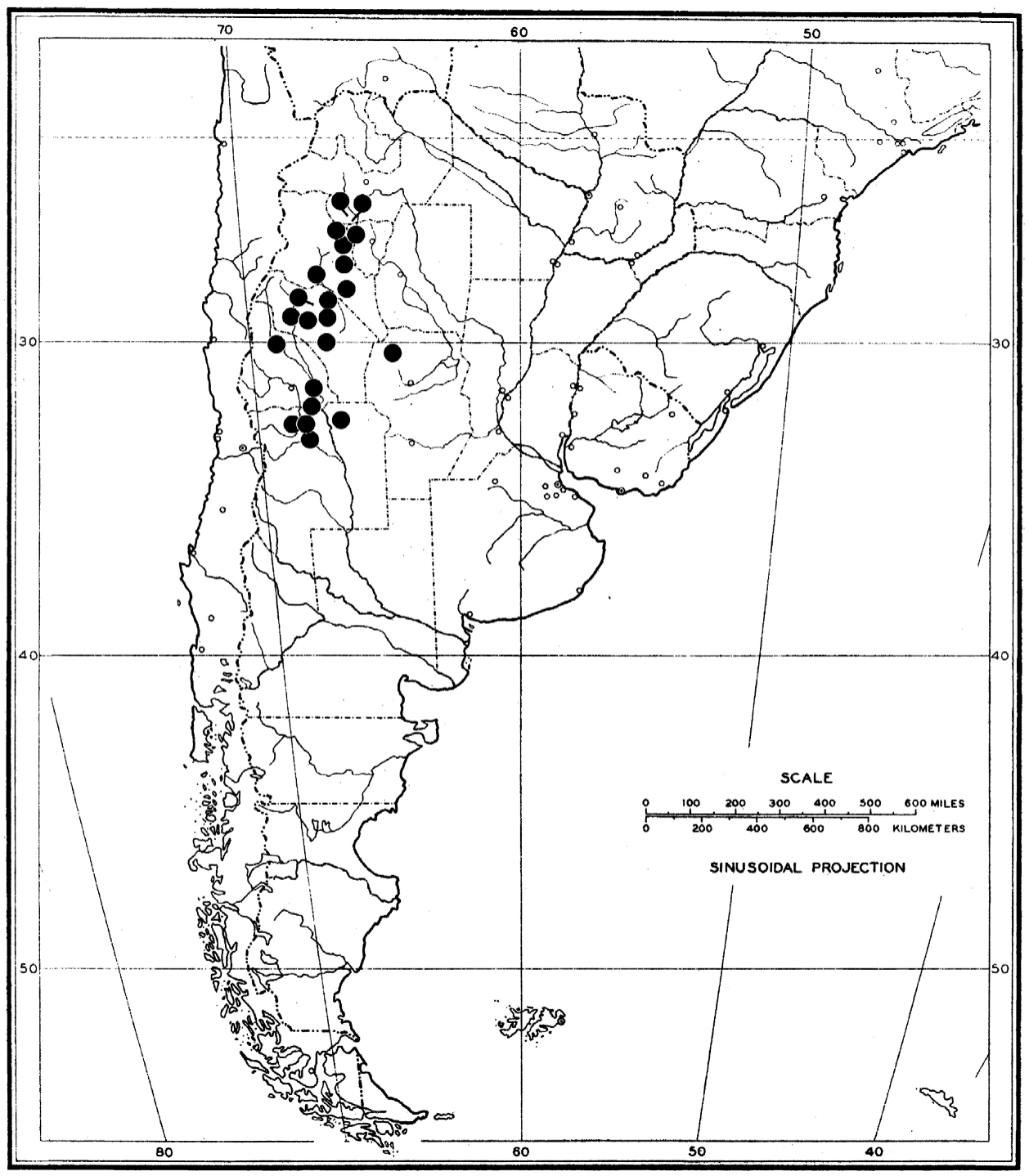

Figure 6. Distributional map of Anomiopsoides heteroclyta (Blanchard). 


\section{Anomiopsoides heteroclyta (Blanchard, 1845)}

(Figures 1, 2f, g, 6)

Anomiopsis heteroclytus Blanchard 1845, p 156.

Anomiopsis furciferum Burmeister 1861, p 64.

Anomiopsis heteroclytum Burmeister 1873, p 406 (nec Blanchard 1845).

Anomiopsis heteroclytum Martínez 1945a, p 266 (nec Blanchard 1845).

Anomiopsis pereirai Martínez 1944, p 39, new synonym.

Anomiopsoides xerophila Martínez 1945b, p 395, new synonym.

Anomiopsoides aberrans Martínez 1945b, p 403, new synonym.

Type material

Anomiopsoides heteroclyta Blanchard, holotype male at MNHN labeled: “129/38”; “Anomiopsis/heteroclytus/Blanch” (handwritten); “ TYPE.” Anomiopsis pereirai Martínez, holotype male at MACN labeled: “Anomiopsis pereirai”/”sp. n. Martínez det. 1944”; “HOLOTIPO.”

New synonymy. Anomiopsoides xerophila Martínez, holotype male at MACN labeled: "ARGENTINA/CORDOBA/C. del Monte/Uritorco/Förster-legit/17 Ene 941”; “Anomiopsoides xerophila/ sp. n./A. Martínez det. 1945." "HOLOTIPO.”

New synonymy. Paratype male at CMNC labeled: "ARGENTINA/CORDOBA/C. del Monte/ Uritorco/Förster-legit/17 Ene 941”; “Anomiopsoides xerophila/sp. n./A. Martínez det. 1945”; "PARATIPO.” Anomiopsoides aberrans Martínez, holotype male at MACN labeled: “ARGENTINA/CATAMARCA/ANDALGALA/DAGUERRE LEG./24-11-45”; “Anomiopsoides aberrans/ sp. n./A. Martínez det. 1945”; "HOLOTIPO.”

New synonymy. Paratype female at CMNC labeleld: "ARGENTINA/CATAMARCA/ANDALGALA/DAGUERRE LEG./24-11-45”; “Anomiopsoides aberrans/sp. n./A. Martínez det. 1945;” "PARATIPO."

There are no character-based differences between A. heteroclyta (Blanchard), A. xerophila Martínez, A. pereirai (Martínez), and A. aberrans Martínez, and so I place these species in synonymy.

\section{Other material studied}

Ninety-six males and 126 females (ABTS, BCRC, BMNH, CMNC, CNCI, FCOC, IADIZA, LEMQ, MACN, MLJC, MLPA, MLUH, MNHN, USNM).

\section{Description}

Male Length 10.0-18.25 mm, width 7.3-14.2 mm. Color dark black, surface shiny to matte.

Head (Figures 1, 2f) Shape subrectangular, transverse. Frons slightly foveate to punctate. Frontoclypeal and clypeogenal suture evident. Frontoclypeal suture elevated entirely or only on sides, sinuate. Clypeogenal surface strongly foveate. Genal posterior angle rounded; lateral margin irregular, setose. Clypeal surface strongly obliquely angled downwards to perpendicular with respect to surface of frons; ventral surface absent; ventral process developed, acute. Clypeal medial process developed, reflexed, parallel, slightly convergent, or slightly divergent; dorsal and external surface strongly foveate, apex smooth; internal surface smooth to slightly foveate, ventral half with fringe of setae; inner margin straight or slightly curved; external margin straight or slightly curved; apex rounded or acute, divergent, reflexed. Clypeal lateral process developed, apex pointed, with one lateral tooth. 
Pronotum (Figure 1) Surface punctate, punctures moderately dense to sparse, small to moderate in size. Lateral margin with long, dense setae on basal half, and moderately dense, short setae on apical half; bead denticulate on apical half.

Elytron Striae variably impressed, punctate; punctures variably impressed, small. Intervals with or without minute tubercles.

Venter Metasternum with small, apical and posterior longitudinal depressions.

Legs Protibial teeth with pointed or rounded apex. Protibial spur curved at apex or not. External mesotibial spur straight or slightly curved on apical third, apex pointed.

Female Length 9.7-17.3 mm, width 7.2-12.7. As male except in the following respects: clypeus with surface obliquely angled downwards with respect to surface of frons, ventral surface developed; ventral process developed, acute (Figure 2g). Clypeal medial process developed; dorsal and external surface strongly foveate, apex smooth; internal surface densely foveate; inner and external margins slightly sinuous; apex rounded or acute, reflexed or not (Figure $2 \mathrm{~g}$ ).

\section{Variation}

Anomiopsoides heteroclyta shows substantial variation in the shape of the medial clypeal processes. These processes vary in length and width at the base and at the apex. Most specimens have their clypeal processes parallel, but different degrees of convergence or divergence toward the apex was observed in some specimens. Variation of the elytral and pronotal puncture density, puncture size, and elytral striae impression was also observed.

\section{Diagnosis}

Males of this species are recognized by the clypeal surface perpendicularly angled downwards with respect to the surface of the frons (Figures 1, 2f); the ventral surface absent; the clypeal medial process developed and reflexed, with the inner margin straight or slightly curved, and the external margin straight or slightly curved, and the apex divergent, reflexed; and the clypeal lateral process developed, with one poorly developed lateral tooth (Figure 2f). Females of this species are recognized by the clypeus with the medial processes short (shorter or as long as the length of frons plus length of clypeus), apex pointed; and clypeal surface not perpendicular in frontal view with respect to surface of frons and between clypeal medial processes (Figure 2g).

\section{Distribution (Figure 6)}

Argentina: Catamarca: Andalgalá (1); Los Angeles (1); Punta de Balasto (27); Salado (3); Santa María (1); Santa María (2 km N) (3); Tinogasta (8); no data (16). La Rioja: Aimogasta (45); Anillaco (35) Chañarmuyo (1); Chilecito (2); Chilecito (12 km N) (1); Famatina (4); La Unión (3); Patquía (1); Udpinango (7); Villa Unión (5 km N) (1); Vinchita (10 km S) (1). Mendoza: El Borbollón (1); Lavalle (1); Lavalle, Ruta 142 km 45 (3); Las Catitas (7 km S) (3); Las Catitas (50 km N) (4). Córdoba: Capilla del Monte, Uritorco (2). Salta: Alemania (1); Alemania (20 km S) (1); Cafayate (26); Cafayate (8 km NW) (3); Quilmes ruins (6); no data (8). San Juan: Bermejo (1); Encón (12 km E) (62); Jachal (1); no data (1). San Luis: Bella Vista (1). Tucumán: Amaichá del Valle (1). 
Temporal distribution January (107), February (32), March (5), April (2), October (1), November (29), December (11).

Remarks

Two specimens from Argentina (Tinogasta) deposited at CMNC labeled "PARATYPO” by Martínez, should not be considered as paratypes since Blanchard $(1841,1845)$ did not study material from that locality, and it does not constitute part of the original type series (see Blanchard 1845; Martínez 1945b).

\section{Checklist of the tribe Eucraniini (Scarabaeidae: Scarabaeinae)}

EUCRANIINI Burmeister 1861, p 55.

ENNEARABDINA Martínez 1959, p 60.

Ennearabdus Lansberge 1874, p 143. Ennearabdus lobocephalus (Harold 1868, p 84). (Onthophagus)

EUCRANIINIA Burmeister 1861, p 55.

Anomiopsoides Balckwelder 1944, p 197.

Anomiopsis Burmeister 1861, p 62 (nec Westwood 1837), pre-occupied, unavailable.

Anomiopsoides aurita (Burmeister 1861, p 63). (Anomiopsis)

Anomiopsoides biloba (Burmeister 1861, p 63). (Anomiopsis)

Anomiopsis biloba var. schaefferi Martínez 1944, p 40, synonym.

Anomiopsoides catamarcae Martínez 1945b, p 400.

Anomiopsoides cavifrons (Burmeister 1861, p 63) (Anomiopsis).

Anomiopsoides heteroclyta (Blanchard 1845, p 156) (Anomiopsis).

Anomiopsis furciferum Burmeister 1861, p 64, synonym.

Anomiopsis heteroclytum Burmeister 1873, p 406 (nec Blanchard 1845), synonym.

Anomiopsis pereirai Martínez 1944, p 39, synonym.

Anomiopsoides xerophila Martínez 1945b, p 395, synonym.

Anomiopsoides aberrans Martínez 1945b, p 403, synonym.

Eucranium Brullé 1834, p 286.

Anomiopsis Westwood 1837, p 13, (nec Burmeister 1861), synonym.

Cyclodema Laporte 1840, p 68, synonym.

Psammotrupes Guérin-Méneville 1838, p 45, synonym.

Eucranium arachnoides Brullé 1834, p 286.

Eucranium arachnoides Dejean 1833, p 135, invalid name.

Anomiopsis dioscorides Westwood 1837, p 13, synonym.

Pachysoma lacordairei Laporte 1840, p 68, synonym.

Eucranium cyclosoma Burmeister 1861, p 60.

Eucranium dentifrons (Guérin-Méneville 1838, p 46) (Psammotrupes).

Anomiopsis aelinanus Blanchard 1841, Plate 10, synonym.

Eucranium lepidum Burmeister 1861, p 61.

Eucranium planicolle Burmeister 1861, p 61.

Eucranium pulvinatum Burmeister 1873, p 405.

Eucranium simplicifrons Fairmaire 1893, p 608. 
Glyphoderus Westwood 1838, p 163.

Glyphiderus, Westwood 1838, p 164.

Glyphoderus centralis Burmeister 1873, p 407.

Glyphoderus monticola Burmeister 1861, p 67.

Glyphoderus sterquilinus (Westwood 1837, p 13) (Anomiopsis).

\section{Acknowledgements}

I thank Brett Ratcliffe (University of Nebraska-Lincoln) for his critical review of the manuscript. I am grateful to Lee Herman (American Museum of Natural History, New York), Robert Anderson and François Génier (Canadian Museum of Nature, Ottawa, Canada), Roberta Brett (California Academy of Sciences, San Francisco), Andrew Davies (Canadian National Collection of Insects, Ottawa, Canada), Henry Howden (Ottawa, Canada), Sergio Roig-Juñent (Instituto Argentino de Investigaciones de Zonas Aridas, Mendoza, Argentina), Darren Mann (Hope Entomological Collections, Oxford, UK), Terry Wheeler and Stéphanie Boucher (Lyman Entomological Museum, McGill University, Ste. Anne de Bellevue, PQ, Canada), Axel Bachmann (Museo Argentino de Ciencias Naturales, Buenos Aires, Argentina), Juan Schnack and Alberto Machala (Museo de La Plata, La Plata, Argentina), Karla Schneider (Martin-Luther-Universität, Zoologisches Institut, Halle, Germany), Jean Menier (Muséum National d’Historie Naturelle, Paris, France), and Nancy Adams (United States National Museum, Washington, DC) for loans of specimens. This project was supported by an NSF/PEET grant (DEB-0118669) to Mary Liz Jameson and Brett Ratcliffe, by an NSF Biotic Surveys and Inventory grant (DEB 9870202) to Brett Ratcliffe and Ronald Cave, and by a Graduate Student Research Support Award from the Initiative for Ecological and Evolutionary Analysis (IEEA) at the University of Nebraska.

\section{References}

Barbero E, Palestrini C. 1993. Descrizione del terzo stadio larvale di Anomiopsoides cavifrons (Burmeister, 1861). Bollettino della Società Entomologica Italiana 125:53-60.

Blackwelder RE. 1944. Checklist of the coleopterous insects of Mexico, Central America, the West Indies, and South America, Part 2. Bulletin of the United States National Museum 185:189-341.

Blanchard E. 1841. Voyage dans l’Amerique Méridionale par Alcide D’Orbigny. Paris. Plate 10.

Blanchard E. 1845. Voyage dans l’Amerique Méridionale pars Alcide D’Orbigny. Coléoptères. Paris. p 155-184.

Brullé GA. 1834. Histoire Naturelle des Insects 4, Coléoptères I. Paris. 479 p.

Burmeister H. 1861. Die Ateuchiden ohne Fulskrallen, monographisch bearbeitet. Berliner Entomologische Zeitschrift 5:55-67.

Burmeister H. 1873. Lamellicornia Argentina. Stettiner Entomologische Zeitung 34:403-417.

Byrne M, Dacke M, Nordström P, Scholtz C, Warrant E. 2003. Visual cues used by ball-rolling dung beetles for orientation. Journal of Comparative Physiology A: Sensory, Neural, and Behavioral Physiology [online]; doi 10.1007/s00359-003-0415-1.

Cabrera AL. 1976. Regiones Fitogeográficas de Argentina. Enciclopedia Argentina de Agricultura y Jardinería. Tomo II. Fascículo I. Editorial ACME S.A.C.I. Buenos Aires. 85 p.

Cambefort Y. 1991. From saprophagy to coprophagy. In: Hanski I, Cambefort Y, editors. Dung beetle ecology. Princeton (NJ): Princeton University Press. p 22-35.

Dacke M, Warrant E. 2002. Navigation using polarised light in dung beetles [online]; http://www.biol.lu.se/ funkmorf/vision/dan/dung.html

Dejean M. 1833. Catalogue des Coléoptères de la collection de M. Le Comte Dejean, 2(=1). Paris. p 1-175. 
Fairmaire F. 1893. Quelques colèoptéres de la République Argentine. Annales de la Société Entomologique de Belgique 37:608-611.

Gillet JJE. 1911. Pars 38. Scarabaeidae: Coprinae. I. In: Schenkling S, editor. Coleopterorum Catalogus. Berlin: W. Junk. p 1-100.

Guérin-Méneville FE. 1838. In: Laplace. Insectes du voyaje de la Favorite. Magasin de Zoologie 8:1-80.

Halffter G, Edmonds WD. 1982. The nesting behavior of dung beetles (Scarabaeinae): an ecological and evolutive approach. Mexico: Instituto de Ecología. 176 p.

Halffter G, Matthews EG. 1966. The natural history of dung beetles of the subfamily Scarabaeinae. Folia Entomológica Mexicana 12-14:1-312.

Harold E. 1868. Diagnosen neuer coprophagen. Coleopterologische Hefte 4:79-86.

Lansberge JW van. 1874. Deux espèces remarquables de lamellicrones exotiques. Annales de la Société Entomologique de Belgique 17:143-144.

Laporte FL. 1840. Histoire Naturelle des Insectes Coléoptères. Paris. 563 p.

Martínez A. 1944. Insectos nuevos o poco conocidos II. Revista Argentina de Entomología 2:34-40.

Martínez A. 1945a. Insectos nuevos o poco conocidos III (Col. Scarabaeidae). Revista de la Sociedad Entomológica Argentina 12:261-279.

Martínez A. 1945b. Insectos nuevos o poco conocidos IV (Col. Scarabaeidae). Revista de la Sociedad Entomológica Argentina 12:394-409.

Martínez A. 1959. Catálogo de los Scarabaeidae argentinos (Coleoptera). Revista del Mususeo Argentino de Ciencias Naturales Bernardino Rivadavia 5:1-130.

Monteith GH, Storey RJ. 1981. The biology of Cephalodesmius, a genus of dung beetles which synthesizes "dung” from plant material (Coleoptera: Scarabaeidae: Scarabaeinae). Memoirs of Queensland Museum 20:253-271.

Morello J. 1958. La provincia fitogeográfica del monte. Opera Lilloana 2:1-155.

Mostert LE, Scholtz C. 1986. Systematics of the subtribe Scarabaeina (Coleoptera: Scarabaeidae). Entomology Memoir, Department of Agricultural Development, Republic of South Africa 80:1-84.

Ocampo FC. 2003. Evolution of the food relocation behavior of the dung beetle tribe Eucraniini [online]; http://www-museum.unl.edu/research/entomology/Eucraniini.Eucraniini-1.htm

Ocampo FC. 2004. Food relocation behavior and synopsis of the southern South American genus Glyphoderus Westwood (Scarabaeidae: Scarabaeinae: Eucraniini). The Coleopterists Bulletin 58:295-305.

Phillips TK, Scholtz CH, Ocampo FC. 2002. A phylogenetic analysis of the Eucraniini (Coleoptera: Scarabaeidae: Scarabaeinae). Insect Systematics and Evolution 33:241-252.

Roig-Juñent S, Flores G, Claver S, Debandi G, Marvaldi A. 2001. Monte desert (Argentina): insect biodiversity and natural areas. Journal of Arid Environments 47:77-94.

Westwood JO. 1837. Description of several new species of insects belonging to the family of the sacred beetles. Proceedings of the Zoological Society of London 5:12-13.

Westwood JO. 1838. Description of several new species of insects belonging to the family of the sacred beetles. Transactions of the Zoological Society of London 2:153-164.

Wheeler QD, Platnick NI. 2000. The phylogenetic species concept (sensu Wheeler and Platnick). In: Wheeler QD, Meier R, editors. Species concepts and phylogenetic theory. New York: Columbia University Press. p 55-69.

Zunino ME. 1985. Las relaciones taxonómicas de los Phanaeina (Coleoptera: Scarabaeinae) y sus implicaciones biogeográficas. Folia Entomológica Mexicana 64:101-115.

Zunino M, Barbero E, Luzzatto M. 1989. Food relocation behavior in Eucraniina beetles (Scarabaeidae) and the constraints of xeric environment. Tropical Zoology 2:235-240. 